\title{
Determination of Antibiotic and Heavy Metal Resistance in Paenibacillus lautus 51ATA
}

\author{
Elif Canpolat ${ }^{1, a}$, Burcu Biterge-Süt ${ }^{2, b, *}$ \\ ${ }^{1}$ Department of Plant Production and Technologies, Ayhan Şahenk Faculty of Agricultural Sciences and Technologies, Niğde Ömer \\ Halisdemir University, 51240 Merkez/Niğde, Turkey \\ ${ }^{2}$ Deparment of Medical Biology, Faculty of Medicine, Niğde Ömer Halisdemir University, 51240 Merkez/Niğde, Turkey
}

*Corresponding author

\begin{tabular}{|c|c|}
\hline A R T I C L E I N O & A B S T R A C T \\
\hline $\begin{array}{l}\text { Keywords: } \\
\text { Paenibacillus lautus } \\
\text { Antibiotic resistance } \\
\text { Heavy metal resistance } \\
\text { Environmental isolates } \\
\text { Public health }\end{array}$ & $\begin{array}{l}\text { Microbial and chemical contamination is one of the biggest environmental problems since exposure } \\
\text { to pathogenic microorganisms, such as food poisoning bacteria and their biological by-products, are } \\
\text { often associated with disease and allergic reactions. Paenibacillus lautus is an aerobic or facultative } \\
\text { anaerobic opportunistic bacterial pathogen, which is found in a variety of sources. In this study, we } \\
\text { isolated and characterized P. lautus from Nigde Province, which is a wastewater disposal area and } \\
\text { therefore presents a great source of contamination. The bacterial isolate was grown, colony } \\
\text { morphology and Gram-reactions were observed. Bacteria were identified by } 16 \mathrm{~S} \text { rDNA sequencing } \\
\text { analysis, which was performed using DNA samples isolated from pure cultures and amplified by } \\
\text { polymerase chain reaction (PCR). Sequencing results were compared against known bacterial strains } \\
\text { using BLAST (Basic Local Alignment Search Tool) across databases. Antibiotic resistance against } \\
\text { 20 different antibiotics and heavy metal resistance against different concentrations of zinc, copper, } \\
\text { iron, cobalt, chromium and silver containing compounds were tested via disk diffusion method. } \\
\text { Inhibition zones were examined and minimum inhibitory concentrations were recorded. Our results } \\
\text { indicated that P. lautus was resistant to a certain set of antibiotics, while it was sensitive against } \\
\text { others. Similarly, the bacteria were resistant against high concentrations of most metals tested. In } \\
\text { summary, this study provided the first data regarding the isolation and characterization of } \\
\text { Paenibacillus lautus strain from a local source in Turkey, which will account as preliminary data } \\
\text { and guide our future efforts to fight against microbial contaminations. }\end{array}$ \\
\hline
\end{tabular}

elif.yurumez@ohu.edu.tr

(D) https://orcid.org/0000-0003-1470-1169

b@bbitergesut@ohu.edu.tr

https://orcid.org/0000-0001-5756-5756

\section{Introduction}

Clean water is an essential requirement for life. Chemical or microbial contamination of water sources presents an important environmental problem that imposes significant public health risks. Wastewater disposal into water supplies often have permanent toxic effects on the whole ecosystem, including humans (Rehman et al., 2008). One major group of chemical contaminants found in soil, wastewaters and sewers are heavy metals, which at high concentrations have detrimental effects on living organisms (Abskharon et al., 2008). The transition metals, some metalloids, lanthanides, and actinides are collectively called as heavy metals (Singh et al., 2011). These substances do not naturally exist in the environment at high levels; however, in areas of high pollution mainly due to human activity, their concentrations gradually increase (Trevors et al., 1985). Although some heavy metals such as iron, cobalt, copper, manganese and zinc are necessary for the human body, their uptake at higher concentrations are toxic (Chronopoulos et al., 1997, Lane and Morel 2000).
Consumption of heavy metals that accumulate at high levels along the food chain can directly disrupt functionality of vital organs, or the excess heavy metals can compete with other nutritional minerals, blocking them from being utilized by the body (Singh et al., 2011, Lima de Silva et al., 2012).

Several studies have reported the presence of heavy metal resistant microorganisms including Gram-positive or Gram-negative aerobic bacterial strains of Staphylococcus sp., Escherichia coli, Pseudomonas aeruginosa and Bacillus sp. at areas contaminated with wastewaters (Lima de Silva et al., 2012, Marzan et al., 2017, Igiri et al., 2018). Bacteria perceive the toxic effect of high concentrations of heavy metals as a stress condition, which acts as a driving force for them to develop effective mechanisms for tolerance and provides competitive advantage over other bacteria (Guzzo et al., 1999). Genes that offer heavy metal resistance to the bacteria are often carried by bacterial plasmids, which also carry antibiotic resistance genes. 
Therefore, metal resistance is frequently accompanied by antibiotic resistance in bacteria (Trevors et al., 1985). In addition, the detoxifying ability of these resistant microorganisms can be manipulated to detect heavy metals in soil.

This study aimed to isolate and characterize a bacterial strain, namely Paenibacillus lautus from Niğde Province, which is a nearby wastewater disposal area and therefore presents a great source of contamination. Paenibacillus subspecies are defined as Gram-positive facultative anaerobic bacteria that are rod-shaped and form endospores. Paenibacillus species can be isolated from several sources such as soil, salt and sweet water, sewer, sediments, cave areas, composts, plant, insect larvae, and clinical specimens. Due to the resistance of their spores against heat, cold and general disinfectants, they can survive on several environmental surfaces for a long time. Evaluating the antibiotic and heavy metal resistance of $P$. lautus might provide useful insights for future biotechnological applications including development of bioassay indicator organisms.

\section{Materials and Methods}

Isolation and Characterization of Paenibacillus lautus

Mixed bacterial cultures were plated on nutrient agar and incubated at $35^{\circ} \mathrm{C}$ for $24-48$ hours. Following the incubation, colony morphologies and Gram reactions of the isolates were analyzed. In order to characterize the isolate via $16 \mathrm{~S}$ rDNA sequencing analysis, genomic DNA was isolated using a commercially available GF-1 Bacterial DNA Extraction Kit (Vivantis). The purity and concentration of the isolated DNA was measured and visualized by agarose gel electrophoresis. 16S rDNA region was amplified using 27F (5' AGA GTT TGA TCC TGG CTC AG 3') and 1492R (5' GGT TAC CTT GTT ACG ACT T 3') universal primers (Frank et al., 2008). Polymerase Chain Reaction (PCR) consisted of $1 \mu 1$ template DNA (10-100ng), $5 \mu \mathrm{l} 10 \mathrm{X}$ reaction buffer, 0.2 $\mathrm{mM}$ dNTPs, $0.2 \mathrm{mM}$ forward and reverse primers, $1 \mathrm{U}$ Polymerase enzyme and $\mathrm{H}_{2} \mathrm{O}$ to $50 \mu \mathrm{l}$ final volume. Specificity and integrity of PCR products were assessed by agarose gel electrophoresis. Sequencing analysis was performed by BM Labosis (Turkey/Ankara). Sequencing results were analyzed using 4peaks Software and the percentage of similarity against known bacterial strains was determined using BLAST (Basic Local Alignment Search Tool) across databases.

\section{Determination of Antibiotic Resistance Levels}

Disk diffusion method was employed to determine the antibiotic resistance properties of $P$. lautus. Bacteria were grown at $35^{\circ} \mathrm{C}$ for $24-48$ hours to obtain $10^{6}$ cells, which then was plated on nutrient agar. Antibiotic disks containing ampicillin (AM10), Ofloxacin (OFX5), Piperacillin (PRL100), Ciprofloxacin (CIP5), Imipenem (IPM10), Chloramphenicol (C30), Lincomycin (MY10), Penicillin (P10), Oxacillin (OX5), Clindamycin (DA2), Gentamycin (CN10), Cefepime (FEP30), Vancomycin (VA30), Tetracyclin (TE30), Erythromycin (E15), Ceftazidime (CAZ30), Streptomycin (S10), Ticarcillin/clavulanic acid (TIM85), Cefuroxime (CXM30) and Aztreonam (ATM30) purchased from Oxoid
(UK) were placed on solid medium. After incubation at $35^{\circ} \mathrm{C}$ for 24 hours, the diameter of the inhibition zones were measured using a digital compass and compared with tables provided by International Clinical and Laboratory Standards Institute (CLSI) (Wilkins et al., 1972).

\section{Determination of Heavy Metal Resistance}

In order to determine the heavy metal resistance properties of $P$. lautus, disc diffusion method was applied (Hussein et al., 2004). Solutions of Zinc chloride $\left(\mathrm{ZnCl}_{2}\right)$, Copper (II) sulfate $\left(\mathrm{CuSO}_{4}\right)$, Iron (II) sulfate $\left(\mathrm{FeSO}_{4}\right)$, Cobalt (II) chloride $\left(\mathrm{Cl}_{2} \mathrm{Co}\right)$, Potassium chromate $\left(\mathrm{K}_{2} \mathrm{CrO}_{4}\right)$ and Silver nitrate $\left(\mathrm{AgNO}_{3}\right)$ were prepared and the final concentrations of zinc, copper, iron, cobalt, chromium and silver were adjusted to $10 \mathrm{~g} / \mathrm{L}$. The solutions were sterilized by autoclaving at $121^{\circ} \mathrm{C}$ for 15 minutes and concentrations ranging between $25 \mathrm{mg} / \mathrm{L}-10 \mathrm{~g} / \mathrm{L}$ were prepared by serial dilutions. $20 \mu \mathrm{l}$ of each heavy metal containing solution were applied on the discs and placed on agar plates inoculated with $P$. lautus. Inhibition zones were analyzed to determine whether $P$. lautus was resistant against tested heavy metals.

Minimum inhibitory concentration (MIC), which is the lowest concentration that inhibits visible bacterial growth, was determined for each heavy metal by inoculating $P$. lautus into liquid growth medium containing a final concentration of heavy metals ranging between $0,32 \mathrm{mg} / \mathrm{L}$ to $10 \mathrm{~g} / \mathrm{L}$. After 24 hours of incubation, the MIC values were recorded (Khare et al., 2010).

\section{Results}

Our analysis identified the isolated bacteria as sporeforming, Gram-positive and rod-shaped. Comparing the sequencing results obtained after the PCR amplification of the $16 \mathrm{~S}$ rDNA regions of the isolate with known bacterial strains available on NCBI BLAST revealed the isolated bacterial strain as Paenibacillus lautus.

In order to determine the antibiotic resistance in $P$. lautus 51ATA, 20 different antibiotics were tested using disk diffusion method, which indicated that the bacteria were resistant against Ampicillin, Piperacillin, Penicillin, Oxacillin, Cefepime, Ceftazidime, Ticarcillin/clavulanic acid, Cefuroxime and Aztreonam (Figure 1). On the other hand, the bacteria had sensitivity against Ofloxacin, Ciprofloxacin, Imipenem, Chloramphenicol, Lincomycin, Clindamycin, Gentamycin, Vancomycin, Tetracyclin, Erythromycin and Streptomycin (Table 1).

Heavy metal resistance in $P$. lautus 51ATA against six different metals (zinc, copper, iron, cobalt, chromium and silver) was also determined by disk diffusion method. We detected formation of growth inhibitory zones at $7 \mathrm{~mm}, 8$ $\mathrm{mm}, 8 \mathrm{~mm}, 12 \mathrm{~mm}$ and $15 \mathrm{~mm}$ when incubated with 100 $\mathrm{mg} / \mathrm{l}$ silver, $500 \mathrm{mg} / \mathrm{l}$ zinc, $2500 \mathrm{mg} / \mathrm{l}$ iron, 5000mg/l copper and $2500 \mathrm{mg} / \mathrm{l}$ cobalt respectively. Incubation with chromium did not result in a clear inhibition zone even at concentrations as high as $10000 \mathrm{mg} / \mathrm{l}$ (Figure 2). Among all the metals tested, $P$. lautus 51ATA was most tolerant against chromium, whereas the highest sensitivity was observed against silver. Minimal inhibitory concentrations of the heavy metals, in which we determined the lowest concentration that prevents visible growth of $P$. lautus 51ATA, are indicated in Table 2. 


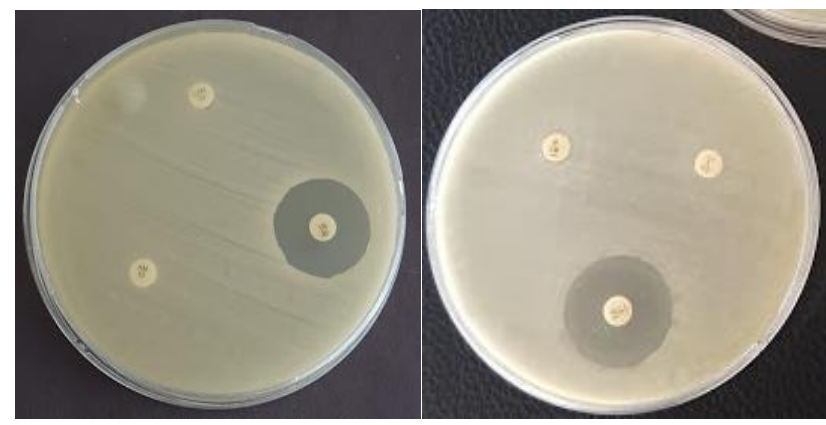

Figure 1 Antibiotic sensitivity of Paenibacillus lautus strain

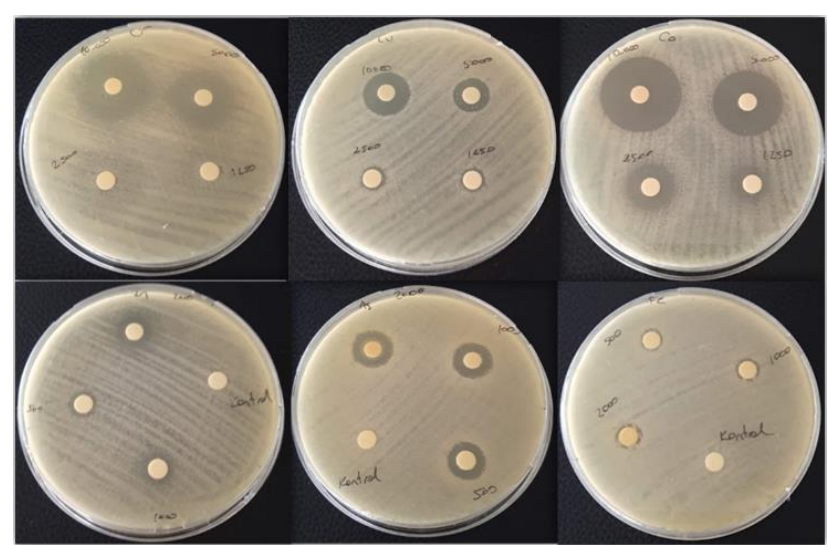

Figure 2 Disk diffusion results of heavy metal resistance in Paenibacillus lautus.

Table 1 Antibiotic susceptibility profiles of Paenibacillus lautus strain.

\begin{tabular}{l|ccc}
\hline \multicolumn{1}{c|}{ Antibiotics } & $\begin{array}{c}\text { Disc content } \\
(\mu \mathrm{g})\end{array}$ & $\begin{array}{c}\text { Growth } \\
\text { Inhibition Zone }\end{array}$ \\
\hline Ampicillin & 10 & $\mathrm{R}$ & \\
Piperacillin & 100 & $\mathrm{R}$ & \\
Ticarcillin/clavulanic acid & 85 & $\mathrm{R}$ & \\
Oxacillin & 5 & $\mathrm{R}$ & \\
Cefepime & 30 & $\mathrm{R}$ & \\
Aztreonam & 30 & $\mathrm{R}$ & \\
Gentamicin & 10 & & $\mathrm{~S}$ \\
Ofloxacin & 5 & & $\mathrm{~S}$ \\
Ciprofloxacin & 5 & & $\mathrm{~S}$ \\
Chloramphenicol & 30 & & $\mathrm{~S}$ \\
Tetracycline & 30 & & $\mathrm{~S}$ \\
Ceftazidime & 30 & $\mathrm{R}$ & \\
Cefuroxime & 30 & $\mathrm{R}$ & \\
Imipenem & 10 & & $\mathrm{~S}$ \\
Vancomycin & 30 & & $\mathrm{~S}$ \\
Penicillin & 10 & $\mathrm{R}$ & \\
Clindamycin & 2 & & $\mathrm{~S}$ \\
Eritromisin & 15 & & $\mathrm{~S}$ \\
Lincomycin & 10 & & $\mathrm{~S}$ \\
Streptomisin & 10 & $\mathrm{~S}$ \\
\hline R & &
\end{tabular}

$\mathrm{R}$ - resistant, IR - intermediate resistant, $\mathrm{S}$ - susceptible

Table 2 Minimal Inhibitory Concentration (MIC, mg/l) of heavy metals for P. lautus growth

\begin{tabular}{l|lllllll}
\hline & Zinc & \multicolumn{2}{l}{ Copper Iron } & Cobalt & Chromium Silver \\
\hline MIC & 2000 & 5000 & 2000 & 2000 & 10000 & 200 \\
\hline
\end{tabular}

\section{Discussion}

Microbial risk assessment of water sources and soil is crucial in terms of public health management, as bacterial and chemical contaminants often result in diseases and allergic reactions. In the present study, we isolated a bacterial strain from a local water source and identified the strain to be Paenibacillus lautus. Several Paenibacillus strains are beneficial bacteria implicated to have plant growth-promoting effects via their ability to fixate nitrogen, solubilize phosphate, induce iron release and produce auxins that regulate cellular activities of plants (Raza and Shen, 2010, Xie et al., 2014, Xie et al., 2016). Furthermore, Paenibacillus species have been shown to produce antimicrobial compounds and insecticides, some of which are used in the medical field such as polymyxins and fusaricidins (He et al., 2007, Bionda et al., 2013). Additionally, genes that render $P$. lautus resistant to heavy metals could be engineered to detect the level of heavy metal contamination in soil. Therefore, here in this paper, we tested the antibiotic and heavy metal resistance of $P$. lautus. There are only a few studies in the literature that investigate the antibiotic resistance in Paenibacillus. Ampicillin, Penicillin and Cephalexin resistance of $P$. lautus is previously reported, which is in line with our finding (Bhullar et al., 2012, Celandroni et al., 2016, Loong et al., 2018). On the other hand, some findings are contradictory to our results, as some isolates of $P$. lautus were resistant against Clindamycin, Chloramphenicol and Erythromycin, which our isolate was sensitive to (Bhullar et al., 2012, Loong et al., 2018). In addition, resistance against Daptomycin, Telithromycin, and Piperacillin is also reported (Bhullar et al., 2012). Moreover, Loong et al. (2018), have mentioned that the antimicrobial susceptibility testing results on their $P$. lautus isolate mirrored that of clinical strains. They have also pointed out that $P$. lautus could be transmitted to host organisms including humans through infected tick bites, emphasizing the importance of taking necessary precautions to be aware of its pathogenic potential and develop safer approaches to limit its transmission (Loong et al., 2018).

Determination of heavy metal resistance revealed that $P$. lautus strain has a high tolerance for most of the tested metals as evident by the high MIC values obtained. This was previously addressed by a study showing that bacteria are often resistant to several metals and contamination with a specific metal induces increased tolerance to not only to the contaminant metal, but also to the others that are present within the environment (Díaz-Ravina et al., 1994). A previous study investigating heavy metal resistance in Bacillus and Paenibacillus sp. showed that Paenibacillus lautus LDB0306 strain has the highest tolerance against metals among the studied bacterial strains (Marais 2012). Others indicated that another Paenibacillus strain, namely $P$. polymyxa is tolerant to different concentrations of $\mathrm{Cu}^{2+}$, $\mathrm{Cd}^{2+}, \mathrm{Zn}^{2+}, \mathrm{Hg}^{2+}, \mathrm{Mn}^{2+}, \mathrm{Ni}^{2+}$ and $\mathrm{Pb}^{2+}$ with $\mathrm{MIC}$ values ranging between $25 \mu \mathrm{g} / \mathrm{mL}-1600 \mu \mathrm{g} / \mathrm{mL}$ (Çolak et al., 2013). Furthermore, five strains of Paenibacillus sp. isolated from $T$. procumbens roots were resistant to $\mathrm{Cu}, \mathrm{Pb}$, $\mathrm{Zn}$ and As (Govarthanan et al., 2016). When compared with other studies in the literature, our results attribute a higher metal tolerance for the $P$. lautus strain that we isolated. 
In conclusion, these results provided the first data regarding the isolation and characterization of Paenibacillus lautus strain from a local source in Turkey, which accounts for preliminary data and guides our future efforts to detect heavy metals in soil.

\section{Conflict of Interest Statement}

The authors declare no financial or non-financial conflict of interest.

\section{References}

Abskharon RNN, Hassan SHA, Gad El-Rab SMF, Shoreit AAM. 2008. Heavy metal resistant of $E$. coli isolated from wastewater sites in Assiut City, Egypt. Bulletin of Environmental Contamination and Toxicology, 81:309-315.

Bhullar K, Waglechner N, Pawlowski A, Koteva K, Banks ED, Johnston MD, Barton HA, Wright GD. 2012. Antibiotic resistance is prevalent in an isolated cave microbiome. PLoS One. 7(4):e34953. doi: 10.1371/journal.pone.0034953.

Bionda N, Pitteloud JP, Cudic P. 2013. Cyclic lipodepsipeptides: a new class of antibacterial agents in the battle against resistant bacteria. Future Med Chem., 5(11):1311-30.

Celandroni F, Salvetti S, Gueye SA, Mazzantini D, Lupetti A, Senesi S, Ghelardi E. 2016. Identification and Pathogenic Potential of Clinical Bacillus and Paenibacillus Isolates. PLoS One. 11(3): e0152831. doi: 10.1371/journal. pone. 0152831 .

Chronopoulos J, Haidouti C, Chronopoulou A, Massas I. 1997. Variations in plant and soil lead and cadmium content in urban parks in Athens, Greece. Sci Total Environ., 196:91-98.

Colak F, Olgun A, Atar A, Yazicioglu D. 2013. Heavy metal resistances and biosorptive behaviors of Paenibacillus polymyxa: Batch and column studies. Journal of Industrial and Engineering Chemistry, 19, 863-869.

Díaz-Ravina M, Baath E, Frostegard A. 1994. Multiple heavy metal tolerance of soil bacterial communities and its measurement by a thymidine incorporation technique. Appl Environ Microbiol., 60(7):2238-47.

Frank JA, Reich CI, Sharma S, Weisbaum JS, Wilson BA, Olsen GJ. 2008. Critical Evaluation of Two Primers Commonly Used for Amplification of Bacterial 16S rRNA Genes. Appl Environ Microbiol., 74(8):2461-70.

Govarthanan M, Mythili R, Selvankumar T, Kamala-Kannan S, Rajasekar A, Chang Y-C. 2016. Bioremediation of heavy metals using an endophytic bacterium Paenibacillus sp. RM isolated from the roots of Tridax procumbens. Biotech., 6, $242,1-7$.

Guzzo J, Diorio DC, Alexander DC and DuBow MS. 1999. Toward understanding metal stress in environment microbial flora. Proceedings of the 8th International Symposium on Microbial Ecology, Canada.

He Z, Kisla D, Zhang L, Yuan C, Green-Church KB, Yousef AE. 2007. Isolation and identification of a Paenibacillus polymyxa strain that coproduces a novel lantibiotic and polymyxin. Appl Environ Microbiol., 73:168-178.
Hussein H, Ibrahim SF, Kandeel K, Moawad H. 2004. Biosorption of heavy metals from waste water using Pseudomonas sp. Electronic Journal of Biotechnology, 1, 7, 38-46.

Igiri BE, Okoduwa SIR, Idoko GO, Akabuogu EP, Adeyi AO, Ejiogu IK. 2018. Toxicity and Bioremediation of Heavy Metals Contaminated Ecosystem from Tannery Wastewater: A Review. J Toxicol., 2018:2568038.

Khare S, Ahmed N, Pant S, Das R. 2010. Characterizationand Evaluation of heavy metal tolerance of bacterialspecies from soil of waste area near Riyan steel rolling mills,Muzaffarnagar, India. Journal of Applied and Natural Science, 2: 88-9 2.

Lane TW, Morel FM. 2000. A biological function for cadmium in marine diatoms. Proc Natl Acad Sci U S A. 97(9):4627-31.

Lima de Silva AA, de Carvalho MA, de Souza SA, Dias PM, da Silva Filho RG, de Meirelles Saramago CS, de Melo Bento CA, Hofer E. 2012. Heavy metal tolerance (Cr, Ag AND Hg) in bacteria isolated from sewage. Braz J Microbiol., 43(4):1620-31. doi: 10.1590/S1517-838220120004000047.

Loong SK, Ishak SN, Lim FS, Khoo JJ, Tan SN et al., 2018. Paenibacillus lautus, an opportunistic bacterial pathogen, isolated from Ixodes granulatus Supino (Acari: Ixodidae) collected from a Müller's giant Sunda rat (Sundamys muelleri) Systematic \& Applied Acarology 23(4): 597-602. http://doi.org/10.11158/saa.23.4.2

Marais L. 2012. Characterization of bacteria isolated from a platinum mine tailings dam, Environmental Sciences, School of Biological Sciences, North-West University (thesis)

Marzan LW, Hossain M, Mina SA, Akter Y, Chowdhury AMMA. 2017. Isolation and biochemical characterization of heavy-metal resistant bacteria from tannery effluent in Chittagong city, Bangladesh: bioremediation viewpoint. Egypt. J. Aquat. Res., 43 pp. 65-74.

Raza W, Shen Q. 2010. Growth, Fe3+ reductase activity, and siderophore production by Paenibacillus polymyxa SQR-21 under differential iron conditions. Curr Microbiol. 61(5):390-5.

Rehman W, Zeb A, Noor N, Nawaz M. 2008. Heavy metal pollution assessment in various industries of Pakistan. Environ Geol., 55: 353-358.

Singh R, Gautam N, Mishra A, Gupta R. 2011. Heavy metals and living systems: An overview. Indian J Pharmacol. 43(3):24653. doi: $10.4103 / 0253-7613.81505$.

Trevors JT, Oddie KM, Belliveau BH. 1985. Metal resistance in bacteria. FEMS Microbiol. Rev.32 (1): 39-54.

Wilkins TD, Holdeman LV, Abramson IJ, Moore WEC. 1972. Standardized single disc method for antibiotic susceptibility testing of anaerobic bacteria. Antimicrob Agents Chemother., $1(6): 451-9$.

Xie JB, Du Z, Bai L, Tian C, Zhang Y, Xie JY, et al. 2014. Comparative genomic analysis of N2-fixing and non-N2fixing Paenibacillus spp.: organization, evolution and expression of the nitrogen fixation genes. PLoS Genet.;10:e1004231.

Xie J, Shi H, Du Z, Wang T, Liu X, Chen S. 2016. Comparative genomic and functional analysis reveal conservation of plant growth promoting traits in Paenibacillus polymyxa and its closely related species. Sci Rep. 6:21329. doi: $10.1038 /$ srep21329. 